\title{
Low-Temperature Active Pt-catalysts Supported on Mesoporous Silica and Metal-Silicates for Cleaning Diesel-NOx Exhausts
}

\author{
Tamikuni Komatsu' ${ }^{1}$, Keizo Tomokuni ${ }^{2}$, Mitsuo Konishi ${ }^{2} \&$ Takashi Shirai $^{2}$ \\ ${ }^{1}$ Inter-University Research Institute Corporation High Energy Accelerator Research Organization (KEK), \\ Tsukuba, Ibaraki, Japan \\ ${ }^{2}$ The Noguchi Institute, 1-8-1 Kaga, Itabashi-Ku, Tokyo, Japan \\ Correspondence: Tamikuni Komatsu, Inter-University Research Institute Corporation High Energy Accelerator \\ Research Organization (KEK), 1-1 Oho, Tsukuba, Ibaraki 305-0801, Japan. E-mail: BRA01367@nifty.com
}

Received: April 9, $2012 \quad$ Accepted: April 20, $2012 \quad$ Online Published: May 27, 2012

doi:10.5539/ijc.v4n3p24 URL: http://dx.doi.org/10.5539/ijc.v4n3p24

\begin{abstract}
New Pt-catalysts supported on mesoporous silica (MPS) and metal-silicates, which have high de-NOx capabilities over $70 \%$ in NOx-conversion at temperatures around $170{ }^{\circ} \mathrm{C}$ under lean conditions, were developed. A new prototype honeycomb supporting Pt-catalyst allows high de-NOx of diesel-exhausts possible over the wide temperature range of $170-400^{\circ} \mathrm{C}$. The low-temperature activities of the catalysts are well correlated with the Brønsted acidity of the support materials. In view of the reaction mechanism of the de-NOx processes, the Brønsted acid-sites of the supports probably stimulate the oxidation of $\mathrm{NO}$ into $\mathrm{NO}_{2}$, which is the rate-determining step of de-NOx processes, leading to the low-temperature activities.
\end{abstract}

Keywords: mesoporous silica, low-temperature activity, deNOx, diesel-NOx, kinetics, de-NOx mechanism, support effect

\section{Introduction}

The regulation of greenhouse warming due to $\mathrm{CO}_{2}$ discharged by automobiles has become quite severe all over the world. The forthcoming Euro-6, which is the most strict exhaust emission standard legislation, will be implemented in Europe around 2014 on all the vehicles including light-, medium- and heavy-duty diesel vehicles Because diesel-engines are extremely more fuel-efficient than gasoline engines, changes such as gasoline-autos into diesel-autos have been expected. However, the de-NOx of diesel-exhausts using the currently known HC-SCR catalysts (Iwamoto et al., 1997; Nakatsuji et al., 1998; Shich et al., 1998; Burch et al., 1998; Schieser et al., 1998; Centi et al., 2003; Narula et al., 2005; Irfan et al., 2008; Hickey et al., 2010) is very difficult due to lower exhaust-temperatures $\left(100-200^{\circ} \mathrm{C}\right)$ and low content of reductive $\mathrm{HCs}$ in the complete combustion of diesel-exhausts $\left(24 \% \mathrm{O}_{2}\right.$ concentration). For future catalysts to remove diesel-NOx, high de-NOx potential capabilities at temperatures of $100-200{ }^{\circ} \mathrm{C}$ using minimum diesel-fuels as reducing agents in an atmosphere of excess $\mathrm{O}_{2}$ over $10 \%$ might be required.

We have previously reported the low-temperature active Pt/MPS (platinum-catalyst supported on mesoporous silica) (Komatsu et al., 2006, 2010). This paper describes a prototype Pt/MPS coated honeycomb for practical applications to remove the diesel-NOx. Also, several candidates of low-temperature active catalysts more active than Pt/MPS will be proposed through the elucidation of support effects on the low-temperature activities from the viewpoints of kinetics and reaction mechanisms of the de-NOx processes.

\section{Experimental}

\subsection{Sample Preparation}

Mesoporous silica (MPS) was prepared by a sol-gel method using tetraethyl orthosilicate (TEOS) as the silica-source and dodecylamine as the template. Mesoporous metal-silicates, such as W-, B-, Nb-, Ti-, Al- and Gd-silicate, in which each metal-element is incorporated in the silica-frameworks of the MPS were prepared in a similar manner as above except for the addition of a mixture of TEOS and each metal-element precursor as a source of the silicate. The silica/metal atom ratio was adjusted to 20/1. The experimental details were described in the previous report (Komatsu et al., 2006). The Pt-catalyst supported on MPS (Pt/MPS) and on the silicates (Pt/metal-silicate) were prepared by impregnating each support-material with an aqueous solution of $\mathrm{H}_{2} \mathrm{PtCl}_{4}$ and 
$\mathrm{RhCl}_{3} \cdot 3 \mathrm{H}_{2} \mathrm{O}$, evaporated to dryness at $110^{\circ} \mathrm{C}$, followed by reduction with hydrogen at $300{ }^{\circ} \mathrm{C}$ for $1 \mathrm{~h}$. The precious metal loading of the Pt-catalysts was adjusted at a 5 mass $\%$ Pt -0.3 mass $\% \mathrm{Rh}$.

A mixture of Pt/MPS and the solid oxide was prepared by mixing Pt/MPS (80 mg) and commercially available solid oxides (220 mg). $\mathrm{MoO}_{3}-\mathrm{Bi}_{2} \mathrm{O}_{3}(1: 1), \mathrm{WO}_{3}-\mathrm{Co}_{3} \mathrm{O}_{4}(1: 1), \mathrm{WO}_{3}-\mathrm{CeO}_{2}(1: 1), \mathrm{BaO}_{-} \mathrm{CeO}_{2}$ (1:1) and $\mathrm{ZrO}_{2}-\mathrm{CeO}_{2}$ (1:1) mixture were used. For other additives, the zeolite materials were used. A mixture of Pt/MPS and zeolite was prepared by mixing Pt/MPS $(80 \mathrm{mg})$ and the zeolite $(220 \mathrm{mg})$. Commercially available mordenite, clinoptilolite, erionite, ferrierite, $\beta$-zeolite and A-zeolite were ion-exchanged with an aqueous solution of $\mathrm{MgSO}_{4}$ before adding it to the Pt/MPS.

A prototype Pt/MPS coated honeycomb was prepared using Pt/MPS as follows: a slurry of Pt/MPS mixed with alumina-sol was prepared, coated on a full-size cordierite-honeycomb $(\varphi 143.8 \mathrm{~mm} \times 118 \mathrm{~mm}, 4.5 \mathrm{mil} / 400 \mathrm{cpsi})$, placed into an oven, followed by calcination at $600^{\circ} \mathrm{C}$ for $1 \mathrm{~h}$. The coating mass of Pt/MPS was $76 \mathrm{~g}$ per 1 liter of the honeycomb-support. This Pt/MPS coated full-size honeycomb (abbr. fresh honeycomb) was used for assessment of the de-NOx capabilities. The honeycomb for the aging tests was prepared by aging the fresh honeycomb at $750{ }^{\circ} \mathrm{C}$ for $24 \mathrm{~h}$ in the atmosphere (abbr. aging honeycomb). The Pt/MPS coated mini-honeycombs ( $\varphi 38 \mathrm{~mm} \times 50 \mathrm{~mm}, 56.7 \mathrm{ml}$ in volume) as test pieces were prepared by cutting them out of the above full-size-honeycombs.

\subsection{Characterization of the Samples}

The specific surface areas and pore-size distribution of the supports were measured using nitrogen adsorption at $77 \mathrm{~K}$ and determined by the Brunauer-Emmett-Teller (BET) method and the Barrett-Joyner-Halenda (BJH) method. The pore-structure of the supports was characterized by small-angle X-ray diffraction (SAX) and selected-area electron diffraction (SAED). The crystallite sizes of the catalyst were estimated from the half-width of the (111) reflection by powder XRD measurements and confirmed by high-resolution TEM (HRTEM) observations. The homogeneities of the supports and catalysts were confirmed by field-emission SEM (FESEM), scanning TEM (STEM) and HRTEM observations. The metal content was determined by an inductively coupled plasma mass (ICP-MS) analysis.

\subsection{Aging Testes of the Support Materials and Powder Catalysts}

Hydrothermal treatment of the support materials was carried out by treating each material charged in a column with flowing air containing $10 \%$ steam at the flow rate of $100 \mathrm{ml} \mathrm{min}^{-1}$ at $750^{\circ} \mathrm{C}$ for $5 \mathrm{~h}$. Heattreatment of $\mathrm{Pt} / \mathrm{MPS}$ (powder) was carried out by heating the catalyst under each condition of $600^{\circ} \mathrm{C}-50 \mathrm{~h}, 700{ }^{\circ} \mathrm{C}-50 \mathrm{~h}$ and $800^{\circ} \mathrm{C}-50 \mathrm{~h}$ in the air containing $10 \%$ steam.

\subsection{Measurement of NOx-conversions}

The measurements of the NOx-conversions for Pt/MPS and Pt/metal-silicate were carried out using a three-necked quartz tubular down-flow reactor $(20 \mathrm{~mm}$ i.d. and $400 \mathrm{~mm}$ length). Before charging the catalyst into the reactor, each catalyst $(80 \mathrm{mg})$ was mixed with $1.3 \mathrm{~g}(1 \mathrm{ml})$ of sea-sand $(20-30 \mathrm{mesh})$. The catalyst was charged into the reactor, a small amount of glass wool was placed on the catalyst, followed by placing $10 \mathrm{ml}$ of sea-sand on the glass wool. The mixture of Pt/MPS and the additives was charged into the reactor in a similar manner as described above. The sea-sand is used as a dispersant for achieving a homogeneous gas flow in the reactor. The reactor was then placed in an electric furnace. The temperature of the reactor was increased at the rate of ca. $10 \mathrm{~K} \mathrm{~min}^{-1}$ and held at the prescribed temperature for $10 \mathrm{~min}$. The lean-burn de-NOx measurement was carried out using a lean-syngas comprised of $250 \mathrm{ppm} \mathrm{NO}, 400 \mathrm{ppm} \mathrm{C}_{3} \mathrm{H}_{6}$ and $10 \% \mathrm{O}_{2}$ balanced with He. The rich-burn de-NOx measurement was carried out using a rich-syngas comprised of $250 \mathrm{ppm}$ NO, $4000 \mathrm{ppm}$ $\mathrm{C}_{3} \mathrm{H}_{6}$ and $1 \% \mathrm{O}_{2}$ balanced with He.A flow rate of the syngas was $30,000 \mathrm{ml} \mathrm{h}^{-1}\left(\mathrm{SV}=30,000 \mathrm{~h}^{-1}\right.$, GHSV $=7.5 \mathrm{~m}^{3}$ $\mathrm{h}^{-1}$ per $\mathrm{g}$ of $\mathrm{Pt}$ ).

The measurement of de-NOx capabilities of the Pt/MPS coated honeycomb was carried out using a large tubular down-flow reactor ( $40 \mathrm{~mm}$ i.d. and $400 \mathrm{~mm}$ length). The Pt/MPS coated mini-honeycomb (56.7 $\mathrm{ml}$ in volume) as the test piece was pre-treated at $600^{\circ} \mathrm{C}$ for $1 \mathrm{~h}$ in an oven to stabilize the activities and charged them into the reactor. The reactor was placed in an electric furnace. The temperature of the reactor was increased at the rate of about $10 \mathrm{~K} \mathrm{~min}^{-1}$ and was held at the prescribed temperature for $1 \mathrm{~min}$. The lean-rich de-NOx measurement was carried out by alternately flowing a lean-syngas comprised of $250 \mathrm{ppm} \mathrm{NO}, 400 \mathrm{ppm} \mathrm{C}_{3} \mathrm{H}_{6}$ and $10 \% \mathrm{O}_{2}$ balanced with $\mathrm{He}$ and a rich-syngas comprised of $250 \mathrm{ppm} \mathrm{NO}, 4000 \mathrm{ppm}_{3} \mathrm{H}_{6}$ and $1 \% \mathrm{O}_{2}$ balanced with $\mathrm{He}$ into the reactor at the flow rate of $1.7 \mathrm{~m}^{3} \mathrm{~h}^{-1}$ every $1 \mathrm{~min}\left(\mathrm{SV}=30,000 \mathrm{~h}^{-1}\right.$, GHSV=7.9 $\mathrm{m}^{3} \mathrm{~h}^{-1}$ per $\mathrm{g}$ of Pt). The NOx-measurement of the effluent gas was carried out during a period held at the prescribed temperature using a diminished-pressure chemiluminescence NOx-detector which performs simultaneous detection of the $\mathrm{NO}, \mathrm{NO}_{2}$ 
and $\mathrm{N}_{2} \mathrm{O}$ contained in the effluent gas through an online-system. The result was analyzed based on the experimental NOx-conversions and NO: $\mathrm{NO}_{2}$ ratios. The effluent gas after the $\mathrm{C}_{3} \mathrm{H}_{6}$ combustion was analyzed using a gas chromatograph-mass spectrometer (GC-MS).

\section{Results and Discussion}

\subsection{Characterization and Hydrothermal Resistance of the Support Materials}

The SAX profile of the MPS showed a strong singlet-peak at $2 \theta=2.72{ }^{\circ}(\mathrm{d}=3.25 \mathrm{~nm})$. The SAED images of all the prepared support materials showed hollow patterns. This result indicated that all the support materials are completely disordered in the pore-arrangement. The specific surface area and pore diameter of fresh MPS were $1250 \mathrm{~m}^{2} \mathrm{~g}^{-1}$ and $2.5 \mathrm{~nm}$, respectively. The estimated thickness of the mesopore-walls of the MPS was ca. $2 \mathrm{~nm}$. After the hydrothermal treatment at $700{ }^{\circ} \mathrm{C}-50 \mathrm{~h}$ in the air containing $10 \%$ steam, the specific surface area and mesopore-size of MPS were $1290 \mathrm{~m}^{2} \mathrm{~g}^{-1}$ and $2.2 \mathrm{~nm}$, respectively, which were almost the same as those of the fresh. Based on our experiment, half of the specific surfaces and mesopores of MCM-41 and most of the Al-elements in ZSM-5 were lost upon exposure to the hydrothermal atmosphere. When compared to MCM-41 and ZSM-5, MPS has a very high hydrothermal resistance. The specific surface areas and pore diameters of the fresh silicates were W-silicate $\left(900 \mathrm{~m}^{2} \mathrm{~g}^{-1}, 2.8 \mathrm{~nm}\right)$, B-silicate $\left(1200 \mathrm{~m}^{2} \mathrm{~g}^{-1}, 2.4 \mathrm{~nm}\right), \mathrm{Nb}-$, Ti- and Al-silicate $\left(700-800 \mathrm{~m}^{2} \mathrm{~g}^{-1}, 3.2 \mathrm{~nm}\right)$ and Gd-silicate $\left(1140 \mathrm{~m}^{2} \mathrm{~g}^{-1}, 2.2 \mathrm{~nm}\right)$. After the hydrothermal treatment, the W-, B-, $\mathrm{Nb}$ - and Ti-silicates had decreased specific surface areas of $650-700 \mathrm{~m}^{2} \mathrm{~g}^{-1}$ but had almost the same pore-diameters as those of the fresh ones. The specific surface areas and pore-diameters of the Al- and Gd-silicates before and after the treatment scarcely changed. The Si/metal atom ratios of the $\mathrm{W}-, \mathrm{Nb}-$, Ti- and Gd-silicate were almost unchanged before and after the treatment. However, the B and Al-contents of the silicates decreased to one fifth after the treatment.

\subsection{Heat Resistance of Pt/MPS}

The average diameters of the Pt-particles of the fresh Pt/MPS and Pt/metal-silicate were very close to the pore-diameters of the MPS and the corresponding metal-silicates, respectively. This indicated that the supported Pt-particles are located inside the mesopores of the supports. Certainly, the HRTEM images of the Pt/MPS and $\mathrm{Pt} /$ metal-silicate showed that the supported Pt-particles are close to the pore-diameter of each support and homogeneously distributed on each support particle (the particle size of MPS is $250 \mathrm{~nm}$ average size). The powder XRD measurements of the heat-treated Pt/MPS showed that the average size of the Pt-particles was almost unchanged until $600^{\circ} \mathrm{C}-50 \mathrm{~h}$, then increased to $4-5 \mathrm{~nm}(2-3$ times larger than that of fresh Pt/MPS) after $700{ }^{\circ} \mathrm{C}-50 \mathrm{~h}$, remarkably increased to $10 \mathrm{~nm}$ after $800^{\circ} \mathrm{C}-50 \mathrm{~h}$. That is, the supported Pt-particles were gradually enlarged on the outside of the mesopores of MPS around $700^{\circ} \mathrm{C}$. This is due to the thermal migrations of oxidized Pt-particles because oxidation of metallic Pt occurs around $700^{\circ} \mathrm{C}$. Such an enlargement of the supported Pt-particles predictably decreased the de-NOx activity of the catalyst, as previously reported (Komatsu et al., 2010). It was reconfirmed that up to $600^{\circ} \mathrm{C}-50 \mathrm{~h}$ the NOx-conversion vs. temperature profile of Pt/MPS is unchanged, after $700^{\circ} \mathrm{C}-50 \mathrm{~h}$ the NOx-conversion is not changed, but the corresponding temperature rises to $210^{\circ} \mathrm{C}\left(40^{\circ} \mathrm{C}\right.$ rise $)$, after $800{ }^{\circ} \mathrm{C}-50 \mathrm{~h}$ the NOx-conversion drops to $45 \%(25 \%$ drop $)$ and corresponding temperature rises to $230^{\circ} \mathrm{C}\left(60^{\circ} \mathrm{C}\right.$ rise). The higher temperature shift of the NOx-conversion temperature after the treatment at $700^{\circ} \mathrm{C}-50 \mathrm{~h}$ was confirmed to be gradually restored by reduction with small $\mathrm{HCs}$, such as $\mathrm{CO}$ and $\mathrm{C}_{3} \mathrm{H}_{6}$. The activity of Pt/MPS remaining after aging at $700^{\circ} \mathrm{C}-50 \mathrm{~h}$ corresponds to an estimation of a million-km-travel of the heavy duty diesel cars based on the Arrhenius plots (the logarithm of aging hour vs. 1/T relationships in the range of $\left.400-700^{\circ} \mathrm{C}\right)$.

\subsection{Assessment of Prototype Pt/MPS Coated Honeycombs}

Figure 1 shows the de-NOx profiles for fresh Pt/MPS and aging ones which were measured under lean and rich conditions. Under the lean condition, the de-NOx reaction for fresh Pt/MPS begins around $140^{\circ} \mathrm{C}$, rapidly increases to a maximum (ca. $70 \%$ in NOx-conversion) at $170^{\circ} \mathrm{C}$, followed by a gradual drop. Under the rich condition, the NOx-conversion exponentially increases from $2 \%$ at $140^{\circ} \mathrm{C}$ to $99 \%$ at $210^{\circ} \mathrm{C}$, followed by no change above $210^{\circ} \mathrm{C}$. Since such exponential de-NOx curves under the rich conditionare due to a slight amount of $\mathrm{O}_{2}$ in the rich syngas, the profiles may be made more precipitous with the increasing $\mathrm{O}_{2}$-concentration. The de-NOx curves for the aged Pt/MPS are similar to the simulations in which the fresh curves were assumed to be shifted by ca. $40 \mathrm{~K}$ into the higher temperature region. From Figure 1, it is estimated that fresh Pt/MPS is able to remove ca. $14 \%$ of the lean-burn NOx and ca. $6 \%$ of the rich-burn NOx in the temperature range of $100-200{ }^{\circ} \mathrm{C}$ and that the de-NOx capability of the aged Pt/MPS is only several \%.

Figure 2 shows the de-NOx profiles for the fresh Pt/MPS coated-honeycomb and aged one through the lean-rich cycle.The de-NOx reaction for the fresh honeycomb starts around $150{ }^{\circ} \mathrm{C}$, rapidly increases to $90 \%$ in 
NOx-conversion at $200{ }^{\circ} \mathrm{C}$, is constant at $93 \%$ up to $250{ }^{\circ} \mathrm{C}$, followed by a slow decrease to $70 \%$ at $400{ }^{\circ} \mathrm{C}$. For the aging one, the de-NOx slowly increases from $170^{\circ} \mathrm{C}$ up to $90 \%$ at $250{ }^{\circ} \mathrm{C}$, followed by a slow decrease similar to the fresh. If the unreacted $\mathrm{NO}_{2}$ under the lean condition (the difference between NO-conv. and NOx-conv. in Figure 3) is completely removed, the NOx-conversions in the range of $200-400{ }^{\circ} \mathrm{C}$ are estimated to be $95 \%$. In order to bridge the gaps in the NOx-conversion between the experiment and the above estimation, the addition of several zeolites was found to be very effective (Figure 4). From Figure 2, it is estimated that the fresh honeycomb is able to remove ca. $13 \%$ of the NOxin the temperature range of $100-200{ }^{\circ} \mathrm{C}$ and the aged one is ca. $8 \%$. However, the honeycomb indicates high activities in the range of $150-400{ }^{\circ} \mathrm{C}$. Although the de-NOx profiles for the powder catalyst and honeycomb were different from each other due to the differences in the gas-diffusion and thermal conductivity, the de-NOx capabilities of both catalysts were approximately equal. Since Pt/MPS is able to utilize long-chain HCs contained in diesel-fuels as reducing agents (Komatsu et al., 2010), the honeycomb seems to be very useful to remove the NOx of diesel-auto exhausts by combination of lean-rich techniques and post-injection of minimum diesel-fuels. For future catalysts to resolve the difficult problems regarding the de-NOx of heavy duty diesel-exhausts, wider activities over the temperatures from $100^{\circ} \mathrm{C}$ to $200^{\circ} \mathrm{C}$ are required.

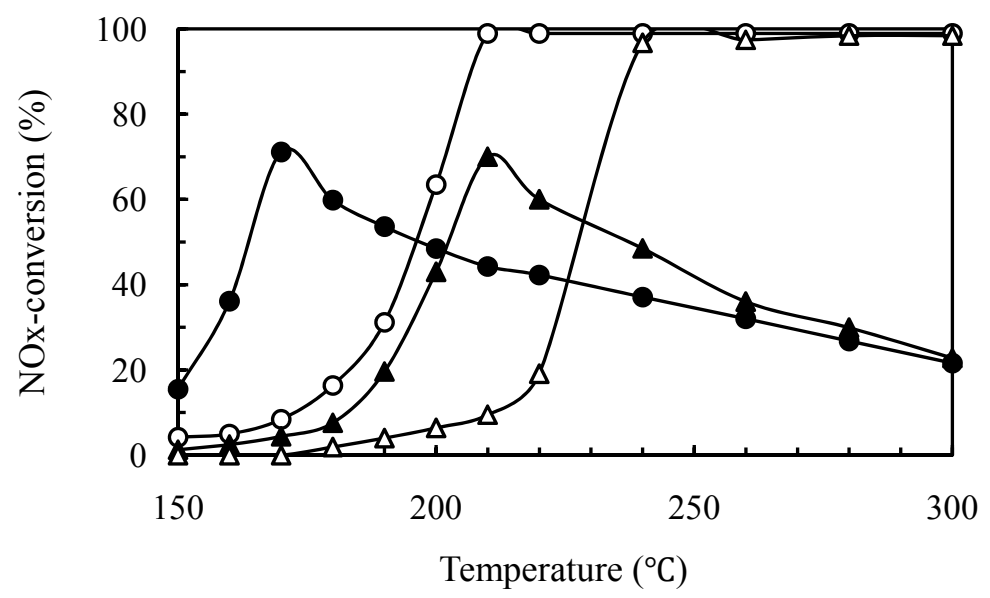

Figure 1. NOx-conversions over fresh Pt/MPS (powder) and aged one under lean and rich conditions: $(\bullet)$ fresh Pt/MPS under the lean condition; ( () fresh Pt/MPS under the rich condition; $(\boldsymbol{\Delta})$ agedPt/MPS under the lean condition; $(\Delta)$ aged Pt/MPS under the rich condition

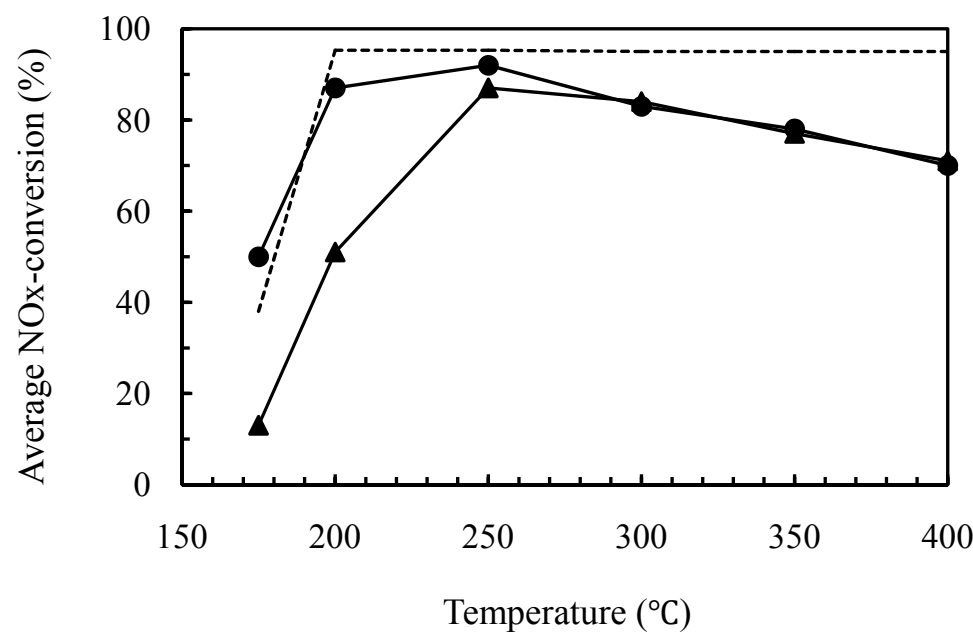

Figure 2. NOx-conversions over the Pt/MPS coated honeycomb through lean (1 min)-rich (1 min) cycles: $(\bullet)$ fresh; $(\boldsymbol{\Delta})$ after aging $\left(750{ }^{\circ} \mathrm{C}-24 \mathrm{~h}\right)$; (---) estimation. The average NOx-conversion is an average of NOx-conversions at lean- and rich-gas flows 


\subsection{The Support Effect on NOx-Conversion vs. Temperature Profiles for Pt/MPS and Pt/Metal-Silicate}

Figure 3 shows the NOx-conversions for Pt/MPS and Pt/metal-silicate with Pt/ $\gamma$-alumina as the reference. The catalysts supported on MPS and the metal-silicates, except for Pt/ $\gamma$-alumina indicate very high NOx-conversions slightly over $70 \%$ at temperatures around $170^{\circ} \mathrm{C}$. Although the NOx-conversion gradually decreases above $170^{\circ} \mathrm{C}$, the NO-onversion increases even at temperatures above $170^{\circ} \mathrm{C}$. Since the difference $\{[\mathrm{NO}-\mathrm{Conv}$. $]-$ [NOx-conv.] $\}$ is equal to the unreacted $\mathrm{NO}_{2}$, a volcano-form of the NOx-conversion curves suggest that below $170^{\circ} \mathrm{C}$ the HC-selective $\mathrm{CR}$ is occurring, and above $170^{\circ} \mathrm{C}$ the HC-nonselective $\mathrm{CR}$ is occurring due to the competition of the oxidation of $\mathrm{NO}$ into $\mathrm{NO}_{2}$ and consumption of the HCs. On the other hand, $\mathrm{Pt} / \gamma$-alumina has NOx-conversions as high as $40 \%$ around $240{ }^{\circ} \mathrm{C}$. The maximum NOx-conversion for Pt/MPS can be raised to ca. $80 \%$ with the decreasing $\mathrm{O}_{2} / \mathrm{C}_{3} \mathrm{H}_{6}$ ratios of the initial syngas at the constant $\mathrm{NO} / \mathrm{C}_{3} \mathrm{H}_{6}$ ratio $(250 / 400)$, however, the maximum value under the standard condition is usually 70-72\%. A light-off temperature of the de-NOx reactions can be dropped to $100^{\circ} \mathrm{Cusing} \mathrm{H}_{2}$ as the reductant, however, the use of $\mathrm{H}_{2}$ is difficult under practical applications due to the high expense.

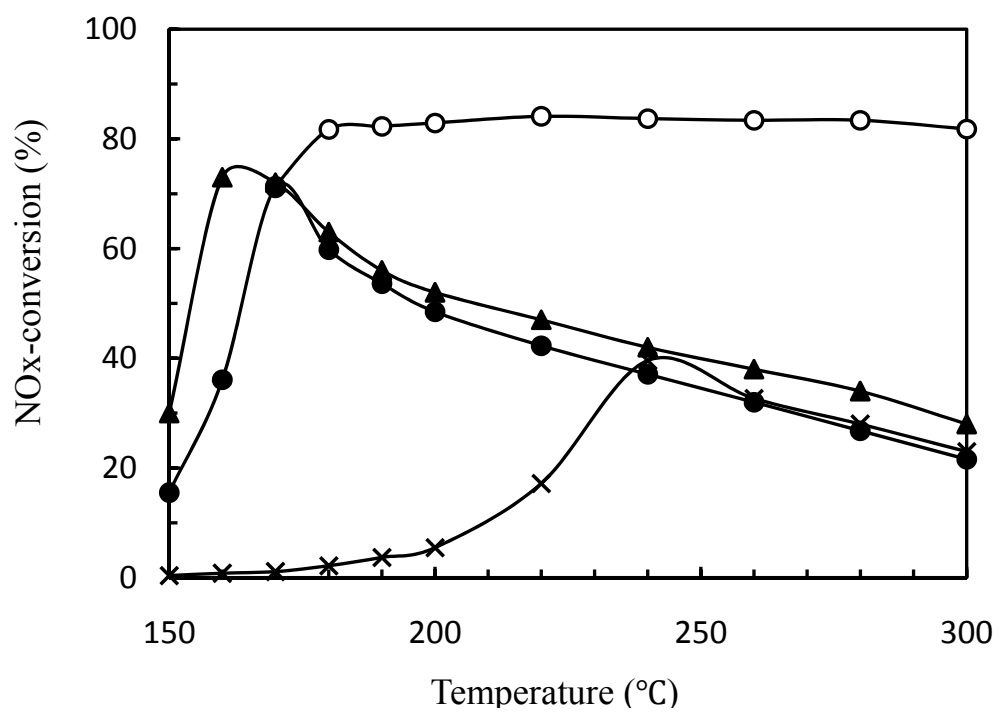

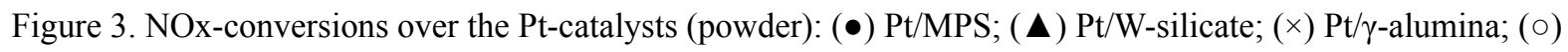
NO-conversion

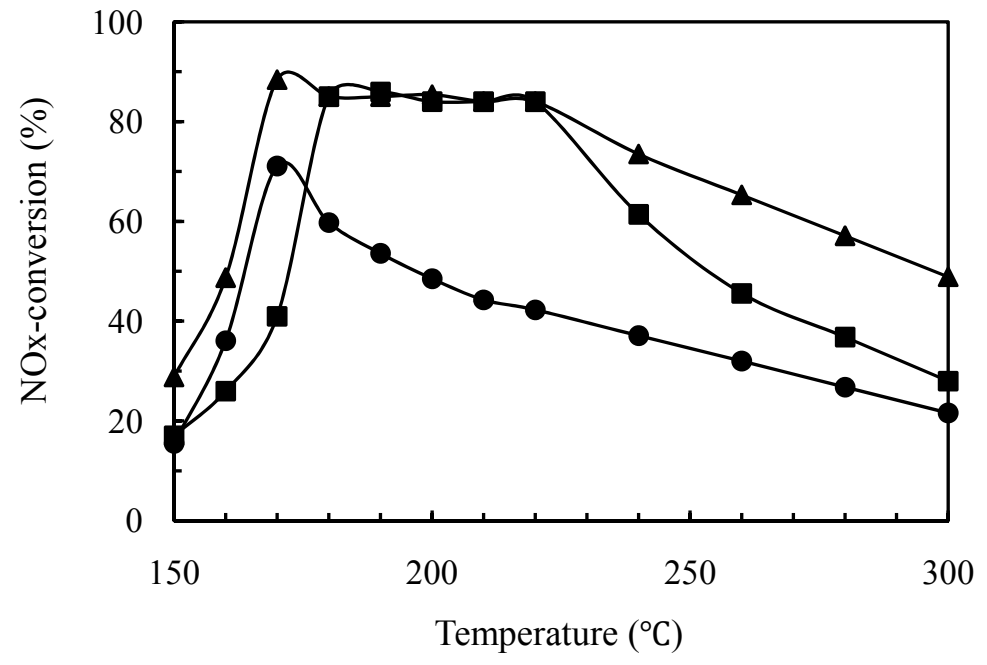

Figure 4. Effects of the additives on NOx-conversions of Pt/MPS: (•) only Pt/MPS; ( $\mathbf{\Delta})$ addition of erionite; addition of mordenite 
Obviously, the MPS and metal-silicate supports produce the catalyst low-temperature activity, while $\gamma$-alumina produces the high-temperature activity. The average Pt-particle sizes of the Pt/MPS and Pt/ $\gamma$-alumina are the same at $2 \mathrm{~nm}$. Both results suggest that the temperature regions in which the catalysts are the most active are related to the support materials (abbr. support effect). The Pt/W-silicate, $\mathrm{Pt} / \mathrm{B}$-silicate and Pt/MPS indicated high NOx-conversions at temperatures lower than $170{ }^{\circ} \mathrm{C}$ in comparison with $\mathrm{Pt} / \mathrm{Nb}-, \mathrm{Ti}-$, Al- and Gd-silicates. Among the catalysts, the de-NOx activity of the Pt/W-silicate was significantly higher than those ofthe $\mathrm{Pt} / \mathrm{B}$-silicate and Pt/MPS. The Pt/W-silicate is able to extend the temperature window of de-NOx by $10^{\circ} \mathrm{C}$ on the lower temperature side in comparison with Pt/MPS as having NOx-conversions higher than that of Pt/MPS (Figure 3). This is unlike the simple temperature shift of the NOx-conversion curve for Pt/MPS.

Whether or not the additions of solid-oxides and several zeolite-materials to Pt/MPS affect the low-temperature activity was investigated. Figure 4 shows the effects of such additives on the NOx-conversion profiles. None of the used solid oxides changed the NOx-conversion profile for Pt/MPS. Even the addition of solid oxides, such as $\mathrm{MoO}_{3}$ and $\mathrm{WO}_{3}$, known as strong solid acids, indicated almost the same profile as that for Pt/MPS. Among the zeolites, the addition of moldenite and erionite increased the NOx-conversions in the range of $170-300^{\circ} \mathrm{C}$, but were only slightly effective below $170^{\circ} \mathrm{C}$. Around the same time as the discovery of HC-SCR of NOx over $\mathrm{Cu}$-Zeolites, classical work for determining the active-sites of zeolites reported that the complex formation and transformation of nitrogen oxides $\left(\mathrm{NO}\right.$ and $\mathrm{N}_{2} \mathrm{O}$ ) with cations and strong Lewis acid sites in zeolites (ZSM-5, MOR, LTA and FAU) yield strong $\mathrm{NO}^{\delta+}$ and $\mathrm{N}_{2} \mathrm{O}_{3}$ species to oxidize $\mathrm{CO}$ and $\mathrm{CH}_{4}$ into $\mathrm{CO}_{2}$ (Kustov et al., 1995). The used zeolites ion-exchanged with Mg-ions in this study have no strong Lewis acid-sites in comparison with those exchanged with transition metal ions such as $\mathrm{Fe}^{3+}, \mathrm{Cu}^{2+}, \mathrm{W}^{6+}, \mathrm{Mo}^{6+}$ and $\mathrm{Co}^{3+}$. The $\mathrm{Mg}$-zeolites in this study are not solid bases because Mg-ions are generally the very weak in their ion-exchange selectivity series: $\mathrm{Cs}^{+1}>\mathrm{Rb}^{+1}>\mathrm{K}^{+1}>\mathrm{NH}_{4}^{+1}>\mathrm{Ba}^{+2}>\mathrm{St}^{+2}>\mathrm{Na}^{+1}>\mathrm{Ca}^{+2}>\mathrm{Fe}^{+3}>\mathrm{Al}^{+3}>\mathrm{Mg}^{+2}>\mathrm{Li}^{+1}$ (Sherry, 2003). Accordingly, the effects of the zeolites used as additives are presumably due to the adsorption of $\mathrm{HCs}$ but not due to the adsorption of $\mathrm{NO}_{2}$ similar to LNT (Lean-NOx-Trap). The present zeolites are not solid bases, such as $\mathrm{BaO}$ usually used as LNT-agents, therefore, the materials have no problems such as deactivation with several ppm SOx (SOx poisoning or stoichiometric sufation). Zeolites, such as HZSM-5 and MCM-41, produce low-temperature activities in the catalyst, as previously reported (Komatsu et al., 2006). These results strongly suggest that the support effect is due to the incorporated metals. The relative support effects dependent upon the incorporated metals tended to increase in the order of $\mathrm{W}>\mathrm{B}>\mathrm{Si}>\mathrm{Nb}>\mathrm{Ti}>\mathrm{Al}>\mathrm{Gd}$. This order is similar to that of the Brønsted acidity of the solid oxides corresponding to the incorporated metals. MPS and the metal-silicates probably possess the Brønsted acid-sites, while $\gamma$-alumina contains Lewis acid-sites. The observation of the Brønsted acid-sites of transition-metal inserted MCM-41 was unsuccessful because of really ineffective pyridine adsorption FT-IR assessment (Zhang et al., 1998; Briot et al., 2000; Parvulescu et al., 2003). Although the measurement of acid-sites of MPS and the metal-silicates by the above standard method is very difficult, the support effect is undoubtedly due to the strong Brønsted acid-sites locally distributed on the support surfaces.

\subsection{The Support Effect from a Kinetic View Point}

A previous study (Komatsu et al., 2010) demonstrated that the rate-determining step of the de-NOx processes over Pt/MPS with $\mathrm{C}_{3} \mathrm{H}_{6}$ as a reducing agent under lean-conditions is the oxidation of $\mathrm{NO}$ into $\mathrm{NO}_{2}$ on the Pt-particle surfaces and that the low-temperature activity of Pt/MPS is due to the exceptionally high frequency factor A $\left(8.6 \times 10^{5} \mathrm{~s}^{-1}\right)$ rather than the apparent activation energy $\mathrm{E}\left(102 \mathrm{~kJ} \mathrm{~mol}^{-1}\right)$ forPt/MPS in comparison with those for Pt/ $\gamma$-alumina $\left(102 \mathrm{~kJ} \mathrm{~mol}^{-1}, 2.6 \times 10^{4} \mathrm{~s}^{-1}\right)$ and Pt/zirconia $\left(101 \mathrm{~kJ} \mathrm{~mol}^{-1}, 5.9 \times 10^{3} \mathrm{~s}^{-1}\right)$. According to the Arrhenius theory, the frequency factor is related to the collision probabilities which are dependent upon the reaction temperatures. The reaction rate constants $\mathrm{k}_{1}$ and $\mathrm{k}_{2}$ for Pt/MPS and $\mathrm{Pt} / \gamma$-alumina are expressed by the Arrhenius eq. (1),

$$
k=A \cdot e\left(-\frac{E}{R T}\right)
$$

where a set of $k_{1}, A_{1}, E_{1}$ and $T_{1}$ is for Pt/MPS and a set of $k_{2}, A_{2}, E_{2}$ and $T_{2}$ is for Pt/ $\gamma$-alumina. $R$ is the gas-constant $\left(8.3144 \mathrm{~J} \mathrm{~K}^{-1} \mathrm{~mol}^{-1}\right)$. A relative reaction rate of $\mathrm{k}_{1} / \mathrm{k}_{2}$ is equal to $A_{1} / A_{2}(=$ ca. 33$)$ when $E$ is equal between both catalysts. The relative $\mathrm{k}_{1} / \mathrm{k}_{2}$ is generally converted to the difference in the reaction temperature $\left(\mathrm{T}_{2}-\mathrm{T}_{1}\right)$ from eq. 2.

$$
k_{1} / k_{2}=A_{1} / A_{2}=e\left(\frac{E(T 2-T 1)}{R T 1 T 2}\right)
$$

A reaction temperature drop corresponding to the ratio of $A_{1} / A_{2}(=$ ca. 33$)$ is estimated to be ca. $70 \mathrm{~K}$ which is 
close to the difference in the NOx-conversion temperature between both catalysts. The thermal energies required for the de-NOx reactions at lower light-off temperatures are supplied by the exothermic reactions, such as oxidations of $\mathrm{NO}$ and the HCs. Also, kinetic analysis of the Pt/metal-silicates in Figure 3 estimates the $\mathrm{Pt} / \mathrm{W}$-silicate $\left(102 \mathrm{~kJ} \mathrm{~mol}^{-1}, 1.7 \times 10^{6} \mathrm{~s}^{-1}\right)$ which are slightly higher or similar to those for Pt/MPS. It has been proposed that the intermediate $\mathrm{NO}^{+}$and carbenium ions are generated from the respective $\mathrm{NO}_{2}$ and $\mathrm{HCs}$ at the Brønsted acid-sites of HZSM-5, both intermediates react to form isocyanates, followed by oxidative decomposition into $\mathrm{N}_{2}$ and $\mathrm{N}_{2} \mathrm{O}$ (Ingelsten et al., 2006). Protons in the hydrothermal phase are strong electrophiles (oxidants) being quite able to stimulate oxidation of $\mathrm{NO}, \mathrm{NO}_{2}, \mathrm{O}_{2}$ and the HCs. A hypothetical scheme that the Brønsted acid-strength of the support materials increases the Arrhenius frequency factor being directly correlated with the oxidation of $\mathrm{NO}$ into $\mathrm{NO}_{2}$ to derive low-temperature activities is conceivable.

\section{Conclusion}

We developed new Pt-catalysts supported on mesoporous silica (MPS) and metal-silicates to remove lean-NOx at temperatures around $170^{\circ} \mathrm{C}$. A prototype honeycomb supporting Pt/MPS allows the high de-NOx of diesel-exhausts possible over the wide temperature range of $170-400^{\circ} \mathrm{C}$. Such remarkable low-temperature activities of the catalysts are dependent upon the supports (abbr. support effect) rather than the supported Pt-particle sizes and specific surface areas of the supports. The support effect is due to the Brønsted acid-sites of the support materials. The kinetic investigation of the de-NOx over the Pt-catalysts predict that the Brønsted acid-sites of the support increase the frequency factors of the oxidation of $\mathrm{NO}$ into $\mathrm{NO}_{2}$ which is the rate-determining step of the de-NOx processes, in other words, that active protons on the Brønsted acid-sites of the support stimulate the oxidation of the $\mathrm{HCs}, \mathrm{NO}$ and $\mathrm{NO}_{2}$ adsorbed on the catalyst to produce the support effect. For future support materials, a strong Brønsted-acid type of material like mesoporous tungsten-silicate, which indicates higher support effects than MPS, appear promising.

\section{References}

Briot, E., Piquemal, J. Y., Vennat, M., Bregeault, J. M., Chottard, G., \& Manoli, J. M. (2000). Aqueous acidic hydrogen peroxide as an efficient medium for tungsten insertion into MCM-41 mesoporous molecular sieves with high metal dispersion. Journal of Materials Chemistry, 4, 953-958. http://dx.doi.org/10.1039/A908428B

Burch, R., \& Waltling, T. C. (1998). The effect of sulphur on the reduction of $\mathrm{NO}$ by $\mathrm{C}_{3} \mathrm{H}_{6}$ and $\mathrm{C}_{3} \mathrm{H}_{8}$ over $\mathrm{Pt} / \mathrm{Al}_{2} \mathrm{O}_{3}$ under lean-burn conditions. Applied Catalysis B: Environmental, 17, 131-139. http://dx.doi.org/10.1016/S0926-3373(98)00007-1

Centi, G., \& Perathoner, S. (2003). Novel catalyst design for multiphase reactions. Catalysis Today, 79-80, 3-13. http://dx.doi.org/10.1016/S0926-5861(03)00036-1

Hickey, N., Boscarato, I., Kaspar, J., Bertinetti, L., Botavina, M., \& Martra, G. (2010). Effect of the support on activity of silver catalysts for the selective reduction of NO by propene. Applied Catalysis B: Environmental, 100, 102-115. http://dx.doi.org/10.1016/j.apcatb.2010.07.019

Ingelsten, H. H., Palmqvist, A., \& Skoglundh, M. (2006). Mechanistic aspect of HC-SCR over HZSM-5: Hydrocarbon activation and role of carbon-nitrogen intermediates. Journal of Physical Chemistry B, 110, 18392-18400. http://dx.doi.org/10.1021/jp063683z

Irfan, M. F., Goo, J. H., \& Kim, S. D. (2008). $\mathrm{Co}_{3} \mathrm{O}_{4}$ based catalysts for NO oxidation and NOx reduction in fast $\begin{array}{lllll}\text { SCR process. Applied Catalysis B: Environmenal, } & \text { 78, 267-274. }\end{array}$ http://dx.doi.org/10.1016/j.apcatb.2007.09.029

Iwamoto, M., Fernandez, A., \& Zengyo, T., (1997). Oxidation of $\mathrm{NO}$ to $\mathrm{NO}_{2}$ on Pt-MFI zeolite and subsequent reduction of NOx by $\mathrm{C}_{2} \mathrm{H}_{4}$ on In-MFI zeolite: a novel de-NOx strategy in excess oxygen. Chemical Communications, 37-38. http://dx.doi.org/10.1039/A606233D

Komatsu, T., Tomokuni, K., \& Yamada, I. (2006). Outstanding low temperature HC-SCR of NOx over platinum-group catalysts supported on mesoporous materials expecting diesel-auto emission regulation. Catalysis Today, 116, 244-249. http://dx.doi.org/10.1016/j/cattod.2006.01.035

Komatsu, T., Tomokuni, K., Konishi, M., \& Shirai, T. (2010). Outstanding HC-SCR of lean NOx over Pt/mesoporous-silica catalysts. The Open Catalysis Journal, 3, 24-29. http://dx.doi.org/10.2174/1876214X01003010024

Kustov, L. M., Smekalina, E. V., Uvarova, E. B., \& Kazansky, V. B. (1995). NOx adsorption complexes on zeolites containing metal cations and strong Lewis acid sites and their reactivity in $\mathrm{CO}$ and $\mathrm{CH}_{4}$ oxidation: 
A spectroscopic study. Studies in Surface Science and Catalysis, 97, 409-415. http://dx.doi.org/10.016/S0167-2991(06)81915-4

Nakatsuji, T., Yasukawa, R., Tabata, K., Ueda, K., \& Niwa, M. (1998). Catalytic reduction system of NOx in exhaust gases from diesel engines with secondary fuel injection. Applied Catalysis B: Environmental, 17, 333-345. http://dx.doi.org/10.1016/S0926-3373(98)00017-4

Narula, C. K., Daw, C. S., Hoard, J. W., \& Hammer, T. (2005). Materials issues related to catalysts for treatment of diesel exhaust. International Journal of Applied Ceramic Technology, 2, 452-466. http://dx.doi.org/10.1111/j.1774-7402.2005.02046.x

Parvulescu, V., Anastasescu, C., Constantin, C., \& Su, B. L. (2003). Mono (V, Nb) or bimetallic (V-Ti, Nb-Ti) ions modified MCM-41 catalysts: synthesis, characterization and catalysis in oxidation of hydrocarbons (aromatics and alcohols). Catalysis Today, 78, 477-485. http://dx.doi.org/10.1016/S0920-5861(02)00330-9

Schieser, W., Vinek, H., \& Jentys, A. (1998). Catalytic reduction of $\mathrm{NO}_{2}$ over transition-metal containing MCM-41. Catalysis Letters, 56, 189-194. http://dx.doi.org/10.1023/A:1019081717797

Sherry, H. S. (2003). Ion exchange (chap. 21). Handbook of Zeolite Science and Technology edited by Auerbach, S. M., Carrado, K. A, \& Dutta, P. K. Marcel Dekker, Inc., New York, NY: Basel.

Shich, A., Satsuma, A., Iwase, M., Shimizu, K., Komai, S., \& Hattori, T. (1998). Catalyst effectiveness factor of cobalt-exchanged mordenites for the selective catalytic reduction of NO with hydrocarbons. Applied Catalysis B: Environmental, 17, 107-113. http://dx.doi.org/10.1016/S0926-3373(98)00003-4

Zhang, Z., Suo, J., Zhang, X., \& Li, S. (1998). Synthesis of highly active tungsten-containing MCM-41 mesoporous molecular sieve catalyst. Chemical Communications, 241-242. http://dx.doi.org/10.1039/A706719D 